\title{
Free, Prior, and Informed Consent (FPIC) in the Yukon: Established Practice or Untravelled Path?
}

\author{
Emily M. W. Martin
}

University of Guelph

Ben Bradshaw

University of Guelph

Abstract: The adoption of the United Nations Declaration on the Rights of Indigenous Peoples (UNDRIP) has catalyzed Indigenous rights conversations in Canada around free, prior, and informed consent (FPIC). Discussions and debates on FPIC are common in scholarly, legal, and political communities, at international and Canadian scales, as all players continue to grapple with understandings of the right to FPIC. The Yukon-where mineral extraction has a long history and a majority of First Nations have self-government and settled land claims-offers an ideal case for assessing how FPIC is being defined and exercised in light of possible mine developments. Semi-structured interviews with key informants representing Yukon governance institutions, and a document review, both completed in 2017, reveal limited explicit engagement with the FPIC concept. This article serves to identify and make sense of this situation in an exploratory way. Three factors are offered to explain what appears to be a lack of engagement by these key Yukon institutions: 1) that modern treaties and associated established governance systems are well respected; 2 ) that key institutions are awaiting federal action; and 3) that explicit engagement with FPIC will eventually surface in the territory, but has been delayed by established governance systems and treaty implementation priorities. This dynamically evolving and yet ambiguous situation creates an opportunity for better dialogue with specific Indigenous communities and governments regarding their unique expectations and understandings of their right to exercise FPIC.

The Northern Review 47 (2018): 113-134 


\section{Introduction}

Let's be honest ... you're not going to get a mining project going forward in the Yukon unless you have the support of First Nations on whose traditional territory you are moving forward. There hasn't been a mine to my knowledge in the past decade without those First Nations essentially giving that consent. So I certainly follow that [Indigenous right to consent] coming from the UN and that commitment from Canada. But I actually think that for resource extraction, particularly in Canada's North, that [consent] is already happening.

- Paul West-Sells, President \& CEO of Casino Mining Corporation, 21 November 2017, Casino Mine public open house, MacBride Museum, Whitehorse

Casino Mining Corporation, a wholly owned subsidiary of Western Copper and Gold, has proposed to develop what would be the largest mine in the history of the Yukon. This open pit copper-gold mine is proposed within the traditional territories of the Selkirk First Nation, the Little Salmon Carmacks First Nation, and the Tr'ondëk Hwëch'in First Nation. In reflecting on Indigenous peoples' right to issue or withhold their consent to projects within their traditional territories, Casino's president and CEO, Paul West-Sells, offers two suppositions: that mines in northern Canada cannot be built without securing consent; and that this consent is routinely being achieved. For an increasing number of mining firms operating in Canada, and seemingly for Canada's federal government, the former point is increasingly intuitive; the latter is less so, and is a key inspiration for this article.

Starting with the former, that mines in northern Canada cannot be built without Indigenous consent, in 2016 the Government of Canada became a supporter "without qualification" (Bennett, 2016) of the United Nations Declaration on the Rights of Indigenous Peoples (UNDRIP), thereby revoking what had, under the previous Conservative government, been ardent objector status (Joffe, 2010). The Liberal Party of Canada under Justin Trudeau had campaigned on a promise to implement UNDRIP and, once elected in October 2015, provided mandate letters to cabinet ministers requiring as much (Trudeau, 2015). One of the rights contained within the UN declaration, which Canada committed to support and implement, is that of free, prior, and informed consent (FPIC): 
States shall consult and cooperate in good faith with the indigenous peoples concerned through their own representative institutions in order to obtain their free and informed consent prior to the approval of any project affecting their lands or territories and other resources, particularly in connection with the development, utilization or exploitation of mineral, water or other resources. (Article 32, UNDRIP, 2007)

Consistent with this articulation, FPIC denotes consent that has been freely given (or withheld) without coercion, intimidation, or manipulation, prior to, or sufficiently in advance of, the issuance of development approvals or the commencement of development activities, and given with sufficient, accessible, and relevant information to enable an informed decision (UNPFII, 2005).

UNDRIP has served to bring attention to FPIC, a concept that had previously been limited to promotion by the International Labour Organization's Convention 169, the "Convention Concerning Indigenous and Tribal Peoples in Independent Countries" (ILO, 1989). FPIC has also been promoted by the private sector through inclusion of the concept in an International Finance Corporation (IFC) Performance Standard and through its adoption by a number of global banks (Torrence, 2017), as well as its incorporation into global certification systems such as the Forest Stewardship Council (FSC) and the emergent Initiative for Responsible Mining Assurance (IRMA). Though UNDRIP is a global set of rights, James Anaya (2014), former UN special rapporteur on the rights of Indigenous peoples, has called specifically for FPIC implementation in the Canadian context. Litigation has also been a force used to advance understandings of consent in Canada, for example Haida Nation v. British Columbia (Minister of Forests) (2004) and Tsilhqot'in Nation v. British Columbia (2014). Though the Supreme Court of Canada did not explicitly use the language of free, prior, and informed consent in either judgment, consent is an evident expectation depending on the severity of impact and the strength of Aboriginal or treaty right (Joffe, 2015; Land, 2017). Notwithstanding the incomplete acceptance of the right of consent in the legal community, popular discourse around FPIC has increased significantly in Canada alongside the reassertion of rights to self-determination by Indigenous communities and public resurgence of Indigenous cultures (Coates \& Favel, 2016; Fontana \& Grugel, 2016; Hanna \& Vanclay, 2013; Papillon $\&$ Rodon, 2017). The FPIC discourse is especially active in the resource extraction and infrastructure sectors, where the idea of Indigenous 
consent is thought to represent a key means of rebalancing relationships between development proponents and Indigenous communities (Papillon \& Rodon, 2017; Ward, 2011).

The Yukon territory-where mineral extraction has a long history and where a majority of First Nations have settled land claims and selfgovernment-offers a fascinating case for assessing how the concept of FPIC is being defined and exercised. Interest in mineral development in the Yukon has amplified of late given three major mine proposals (Coffee Creek, Eagle, and Casino) and a major federal commitment to improve road access to mineral rich areas of the territory (The Canadian Press, 2017). Concurrent with these major infrastructure commitments, the territorial government has publicly committed to reconcile a previously adversarial relationship with First Nations (Silver, 2016). In this context, this article serves to identify how the Yukon's contemporary governance systems address Indigenous consent, and how institutional actors in the Yukon are engaging with the wider discourse on FPIC. To what degree is Indigenous consent as routine in the Yukon as is suggested by Casino Mining Corporation's president?

To pursue this question, a document review was completed to identify the term "consent" or consent-like provisions within mining-relevant governance documents such as the Umbrella Final Agreement (UFA) and the associated final agreements and self-government agreements between individual Yukon First Nations and the territorial and federal governments, and within key legislation, including:

- from the Yukon Department of Energy Mines and Resources, the Quartz Mining Act, the Placer Mining Act, and the Territorial Lands (Yukon) Act;

- from the Yukon Department of Environment, the Environment Act and the Wildlife Act;

- the Yukon Waters Act;

- from the Yukon Department of Tourism, the Historic Resources Act;

- the federal Yukon Environmental and Socioeconomic Assessment Act (YESAA); and

- the federal Yukon Surface Rights Board Act (YSRBA).

Additionally, eleven semi-structured interviews were conducted in Summer 2017 with key informants from the Government of Yukon, the Yukon Water Board, the Yukon Environmental and Socio-economic 
Assessment Board (YESAB), the Council for Yukon First Nations (CYFN), the Yukon Conservation Society (YCS), and consultants in the field. The content of these interviews was coded and assessed to identify and make sense of the state of FPIC in the Yukon. Summarizing both empirical efforts, Indigenous consent is indeed manifest in some of the institutions governing mine development in the Yukon, though consent rights vary across space; counterintuitively, however, the key informants representing many of the Yukon's governance institutions managing resource development were largely silent on the idea of FPIC and its role in mine permitting in the territory. Though this finding offers only an exploratory portrait of institutional engagement with FPIC in the Yukon, the finding nevertheless warrants attention.

The article proceeds in five further parts. In the next section, scholarship is reviewed to highlight current understandings of, and challenges associated with, FPIC. This is followed by a review of the Yukon's governance landscape with an eye to seeing where consent manifests. In section four, findings from the interviews are presented, which gives rise to a discussion in section five. Finally, concluding remarks are offered alongside a call for further research. This call is consistent with a larger research project, of which this article is a part, in partnership with the Little Salmon Carmacks First Nation regarding their expectations of consent for major mine development within their traditional territory. Herein the focus is on institutional perspectives, not Little Salmon Carmacks First Nation perspectives.

\section{Contemporary Understandings of FPIC}

FPIC is a challenging concept, both in its interpretation and its implementation. In light of this, scholarship has emerged around the concept, including much that celebrates its potential. For many reviewers, FPIC is a potent instrument for exercising community agency and selfdetermination (e.g., Anaya 2009b; Hanna \& Vanclay, 2013; Papillon \& Rodon, 2016; Sambo-Dorough, 2016; Ward, 2011). It is within this perspective that FPIC, as an element of UNDRIP, has been characterized as a framework for reconciliation in the Canadian context (Boutilier, 2017; Land, 2017; Papillon \& Rodon, 2017; Truth and Reconciliation Commission, 2015). Other scholars have drawn attention to FPIC's many complexities that often manifest as challenges to its realization (e.g., Fontana \& Grugel, 2017; Newman, 2017; Papillon \& Rodon, 2017). In the remainder of this section, key challenges to FPIC implementation are reviewed as a precursor to, and context for, an assessment of FPIC in the Yukon. 
Notwithstanding its clarification in UNDRIP, the concept of consent is regarded by many as ambiguous, even when it includes the qualifiers "free," "prior," and "informed" (Buxton \& Wilson, 2013; Hanna \& Vanclay, 2013; Lehr \& Smith, 2010; Mahanty \& McDermott, 2013; Newman, 2017; Papillon \& Rodon, 2016; Ward, 2011). With no agreed upon definition of FPIC, some argue that the concept risks abuse (Fontana \& Grugel, 2016; Mahanty \& McDermott, 2013; Newman, 2017; Owen \& Kemp, 2014) and could result in the undeserved legitimization of development projects such as a mine (Hanna \& Vanclay, 2013). Ambiguity around the means by which consent can be established may generate apprehension among those who seek it and those who offer it. The desire for clarity is countered by the assertion that some fluidity and flexibility is key to allowing for contextually appropriate expressions of FPIC. A more flexible, or ambiguous, approach to achieving FPIC might allow the principle to be modified to fit local contexts, rather than be applied as an international panacea (Anaya, 2012; Coates \& Favel, 2016; Mahanty \& McDermott, 2013; Newman, 2017; Papillon \& Rodon, 2017; Ward, 2011).

Given that many scholars see the contextual relevance of FPIC processes as key to achieving successful FPIC ( e.g., Owen \& Kemp, 2014; Papillon \& Rodon, 2017), some suggest that a "made-in-Canada" approach to FPIC is necessary (Coates \& Favel, 2016; Newman, 2017; Papillon \& Rodon, 2017). Scholarship focused on environmental assessment processes has long drawn attention to similar concerns about context, especially in cross-cultural exchanges (e.g., Baker \& McLelland, 2003; Booth \& Skelton, 2011; Dokis, 2015; Irlbacher-Fox, 2009). Common concerns regarding cultural context include the inaccessibility of technical language to many community members; restrictive timelines that prevent full participation; and lack of respect for, or inclusion of, local or traditional governance systems (Baker \& McLelland, 2003; Booth \& Skelton, 2011; Dokis, 2015).

One evident challenge for eliciting and offering FPIC in a contextually appropriate way centres on representation; who can represent an Indigenous community in FPIC negotiations? It is one thing to determine which communities need to be engaged, it is another thing to determine who within a community must be engaged, and who can legitimately issue consent (Boutilier, 2017; Fontana \& Grugel, 2016; Papillon \& Rodon, 2016). This challenge has led some to call for the integration of traditional governance into FPIC negotiations (Buxton \& Wilson, 2013; Lehr \& Smith, 2010). Indeed UNDRIP (2007, Article 32) compels engagement of Indigenous peoples through "their own representative institutions." At the same time, other scholars have drawn attention to the potential for 
traditional governance institutions and practices to disenfranchise certain populations within an Indigenous community (Buxton \& Wilson, 2013; Fontana \& Grugel, 2016; Lehr \& Smith, 2010; MacIntyre, 2007; Mahanty \& McDermott, 2013). Though means exist to mitigate this disenfranchisement (see Buxton \& Wilson, 2013; Fontana \& Grugel, 2016) and, indeed, have been incorporated into standards (e.g., ILO, 2013; IRMA, 2017), this issue adds to the complexity of ensuring appropriate representation in the issuing of FPIC.

Though the creation and adoption of UNDRIP, including the right to FPIC, is presented as a significant step towards the recognition and protection of the rights of Indigenous peoples (Anaya, 2009a; Hanna \& Vanclay, 2013), concerns persist regarding the enforceability of the principles contained within the declaration (Buxton \& Wilson, 2013; Hanna \& Vanclay, 2013; Perreault, 2015; Ward, 2011). Scholars like Newman (2017), Stavenhagen (2009), and Wiessener (2011) find that the UN declaration is limited as a non-binding legal mechanism, which, without legislative support at the nation-state level, may fail to represent real change (Burger, 2009). Others are less inclined to advocate for legislative treatment based on a view that legal enforceability may restrict meaningful implementation (Buxton \& Wilson, 2013; Owen \& Kemp, 2014). Consistent with this view, some scholars have drawn attention to the supra-regulatory means by which FPIC might be achieved in practice including through the use of impact and benefit agreements (IBAs) (e.g., BLC, 2015; Bradshaw \& McElroy, 2014), though others caution that the presence of a contractual agreement between an Indigenous community and a developer cannot be assumed to constitute consent, let alone FPIC (Hanna \& Vanclay, 2013; Papillon \& Rodon, 2016, 2017; St-Laurent \& Le Billon, 2015).

Of course, the ultimate expression of power is the right to say "no." While this right could be assumed to exist with FPIC, scholars are divided as to whether or not the right to FPIC vests would-be impacted Indigenous communities with a veto right over development (Axmann \& Gray, 2016; Boutilier, 2017; Buxton \& Wilson, 2013; Fontana \& Grugel, 2016; Joffe, 2015; Newman, 2017; Papillon \& Rodon, 2017; Shrinkhal, 2014). The preoccupation that FPIC might be interpreted as a veto right is pointed to by many players as one explanation for resistance and slow implementation of the right (Axmann \& Gray, 2016; Boutilier, 2016; Joffe, 2010; Land, 2016; Obed, 2016; Papillon \& Rodon, 2017). Many, including former UN special rapporteur, James Anaya (2009a), believe FPIC should not be interpreted as a veto right (Land, 2016; Saganash, 2016; Sambo Dorough, 2016), but 
rather as a balancing of rights (Joffe, 2015). The realization of a robust expression of consent, which does not assume absolute power (Anaya, 2012; Papillon \& Rodon, 2017), is enormously complex (Land, 2016). Many scholars and practitioners say that this realization can only happen through the creation of a true partnership (Saganash, 2016) or a co-equal relationship (Papillon \& Rodon, 2017) where all parties are respected and commit to working together despite disagreements or fundamental differences.

While scholars have drawn attention to the ways by which the FPIC concept can redress power imbalances in the resource extraction sector (Buxton \& Wilson, 2013; Mahanty \& McDermott, 2013; Owen \& Kemp, 2014; Papillon \& Rodon, 2017; Szawblowski, 2011), others have questioned how equal FPIC's procedural playing field really is (Fontana \& Grugel, 2016). Though the intent of FPIC is to balance power relations among companies, communities, and governments, a true decentring of power involves acknowledging and responding to subtler forms of power, such as dress, venue, and language, that are incredibly difficult to neutralize (Buxton \& Wilson, 2013; Mahanty \& McDermott, 2013). Scholars also point to present community resource barriers in terms of energy, procedural expertise, and technical knowledge, as potential limits to equal participation (Buxton \& Wilson, 2013; Mahanty \& McDermott, 2013; Papillon \& Rodon, 2017). These challenges identified in the literature highlight the complexity of FPIC and the deeply divided debates regarding its implementation.

\section{Yukon's Governance Landscape: Where is Indigenous Consent?}

The Yukon is a region of unique and visionary governance born from grassroots negotiation and tailored to local context. The Yukon has garnered a reputation for distinctive Indigenous governance as it is home to half of the self-governing Indigenous nations within the bounds of Canada, and much of the territory is covered by modern land claims. In 1993 the Umbrella Final Agreement (UFA) was signed, thereby establishing a framework for individual Yukon First Nations to settle their own unique final agreements and associated self-government agreements. As a complement to these individual agreements, Yukon's First Nations coordinate their collective interests and efforts through the Council of Yukon First Nations (CYFN). Today the CYFN is reviewing its mandate, but generally works to coordinate efforts among member First Nations with respect to engaging with the territorial and federal governments and, in the context of resource development, to facilitate communications between industry and First Nation governments. 
To date, eleven of the fourteen Yukon First Nations have signed self-government and final agreements. In signing final agreements, First Nations negotiated new rights to identify "Settlement Lands" in exchange for Aboriginal rights and title to the remainder of their traditional territory. Settlement lands include "Category A lands" for which the First Nation has surface and subsurface rights, and "Category B lands" for which only surface rights are established; in both cases, the right to consent is central. More exactly, UFA Chapters 18.3 and 18.4 identify when the consent of a First Nation is required in order for a would-be mine developer to access existing (at the date the affected land became Settlement Land) and new mineral rights. In addition, Chapter 24 of the UFA outlines the rights and responsibilities of an individual First Nation government, including the right to legislate regarding language, culture, education, and social welfare (UFA, 1993, 24.1), and the right to negotiate the devolution of programs and services (UFA, 1993, 24.3). As a result, in instances where a Yukon First Nation has developed its own legislation, such as a Lands and Resources Act or Mineral Policy, this legislation may establish complementary requirements around the achievement of consent for various activities such as mineral exploration.

The settlement of land claims also saw the creation of the Yukon Surface Rights Board (YSRB), a conflict resolution body. Schedule II of the Act that established the board (the YSRBA) identifies several situations where consent of a Yukon First Nation is required when conflicting interests on the land are apparent. Here too, consent rights are limited to settlement lands, on which limited mining has occurred to date and which represent just $8.5 \%$ of the territory at present (see Figure 1). The Minto Mine, located on the settlement lands of the First Nation of Na-cho Nyak Dun (NND), is the only quartz mining operation located on settlement lands. Further, it was developed before the NND's settlement lands were established.

Consistent with the UFA, the Yukon has its own territorial environmental assessment system, established under the federal Yukon Environmental and Socio-economic Assessment Act (YESAA) and operationalized by the Yukon Environmental and Socio-economic Assessment Board (YESAB). The Act applies to all lands in the Yukon, both settlement and non-settlement lands. Beyond the mandate of general environmental and socio-economic assessment, YESAA (Section 5) contains a number of specific provisions in the interests of Yukon First Nations, including: 
(d) to protect and promote the well-being of Yukon Indian persons and their societies and Yukon residents generally, as well as the interests of other Canadians;

(f) to recognize and, to the extent practicable, enhance the traditional economy of Yukon Indian persons and their special relationship with the wilderness environment; and

(g) to guarantee opportunities for the participation of Yukon Indian persons - and to make use of their knowledge and experience-in the assessment process;

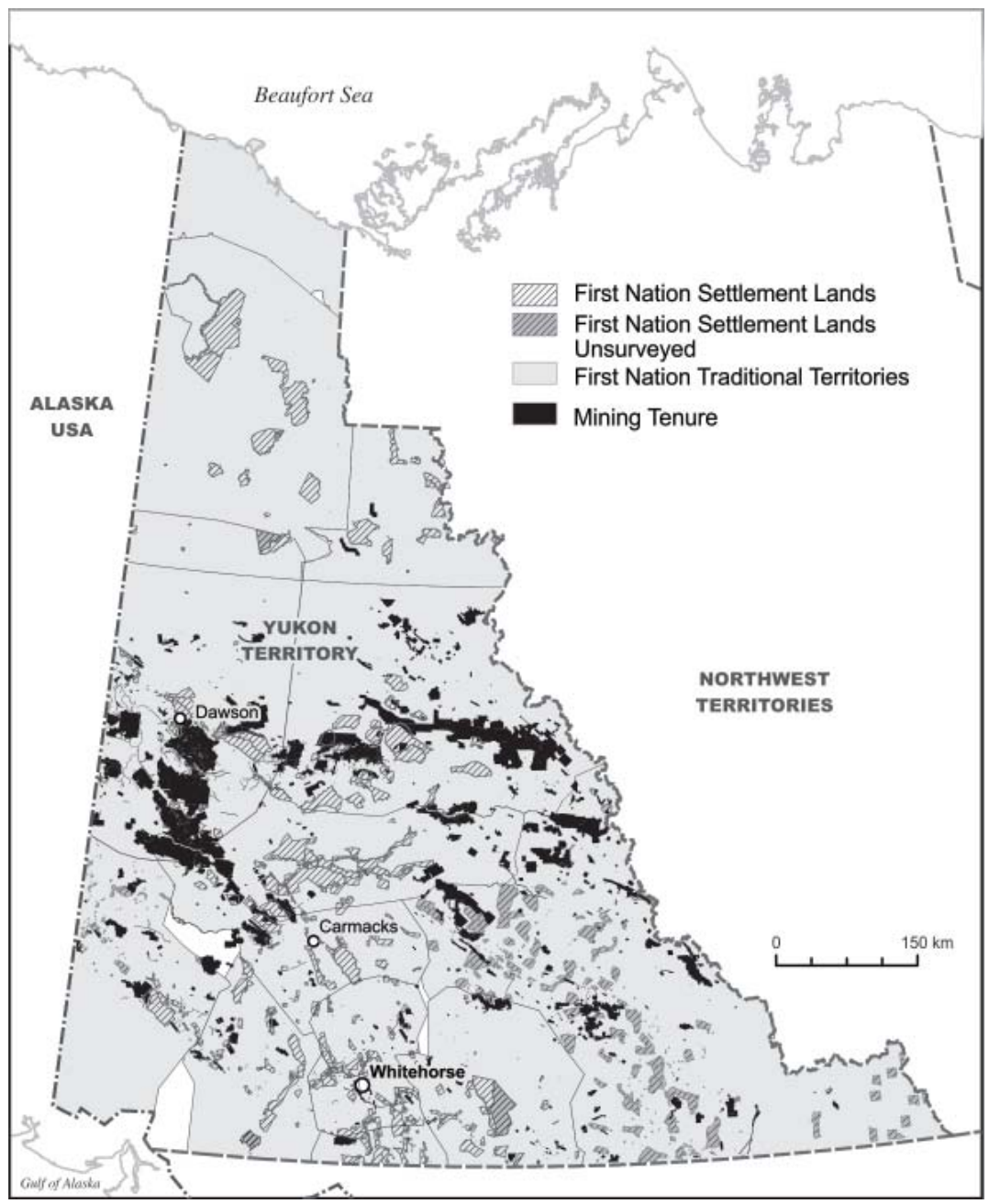

Figure 1. Mining tenure and First Nations settlement lands in the Yukon 
YESAB operates at arm's length from federal, territorial, and First Nation governments, and provides recommendations that are either accepted, rejected, or modified by decision bodies. The decision body is most often a branch of the Government of Yukon, but in specific circumstances, usually limited to settlement lands, a First Nation may also serve as a decision body thereby creating a possible consent mechanism. Further authority is established through the issuance of permits or licences by the appropriate regulators. To build and operate a mine in the Yukon requires the securing of a Quartz Mining Licence from the Energy, Mines, and Resources (EMR) department of the Yukon government and a Water Licence from the Yukon Water Board. These permits were referred to by one key informant as "show stoppers"; if withheld, a project can be stalled or effectively terminated. Depending on the particulars of final agreements, some Yukon First Nations have permitting authority on their settlement lands. If the activity is proposed to take place on Category $B$ land, the First Nation concerned is a decision body (UFA, 12.13.1; YESAA, 2.1). If the activity is proposed to take place on Category A land, the First Nation concerned is both a decision body (UFA, 12.13.1; YESAA, 2.1) and a permitting authority (UFA, 18.3; UFA, 18.4). Thus proponents are required to secure permits from the respective First Nation in addition to permits from the territorial government and Water Board. In the words of one regulator: "[If the project is partially on Settlement Land] we [the Yukon Government] will issue the permit. But the proponent is stuck. Because they can't operate without the permit from the First Nation."

More rarely, YESAB has also been used as a vehicle for a Yukon First Nation to exercise consent-like influence. For example, in the summer of 2017, YESAB discontinued its assessment of Goldcorp's Coffee mine because the Tr'ondëk Hwëch'in, Na-cho Nyak Dun, and Selkirk First Nations submitted to YESAB that Goldcorp had not met its obligation to consult (Garrison, 2017). Though YESAB is technically only a recommending body, not a decision-maker, without its assessment and recommendations, decision bodies cannot make decisions and hence a project cannot proceed. In a similar vein, Yukon First Nations that have not signed final agreements have been able to exert authority over development on large parcels of traditional territory by removing land from the freeentry staking system through litigation (e.g., Ross River Dena Council v. Government of Yukon, 2012). The Ross River Dena Council (representing Kaska people) questioned the territorial government's authority to register claims on its traditional territory without consultation, and a ruling in their favour resulted in a staking moratorium on this territory that 
continues today (Commissioner of Yukon, 2013; Thomson, 2017; Yukon Court of Appeal, 2012). The staking moratorium was expanded in 2017 to include a greater portion of Kaska-asserted traditional territory outside of the Ross River area (Commissioner of Yukon, 2017). Combining these two areas with other areas withdrawn from staking, including various parks and the Peel Watershed, means that about half of the Yukon territory is currently withdrawn from free-entry staking (see Figure 2).

Although the Ross River Dena Council is not opposed to mineral development generally (CBC News, 2013, September 23), the staking moratorium could be interpreted as a vehicle through which they have asserted and reclaimed some authority over development in their traditional territory without explicit invocation of their right to consent to development.

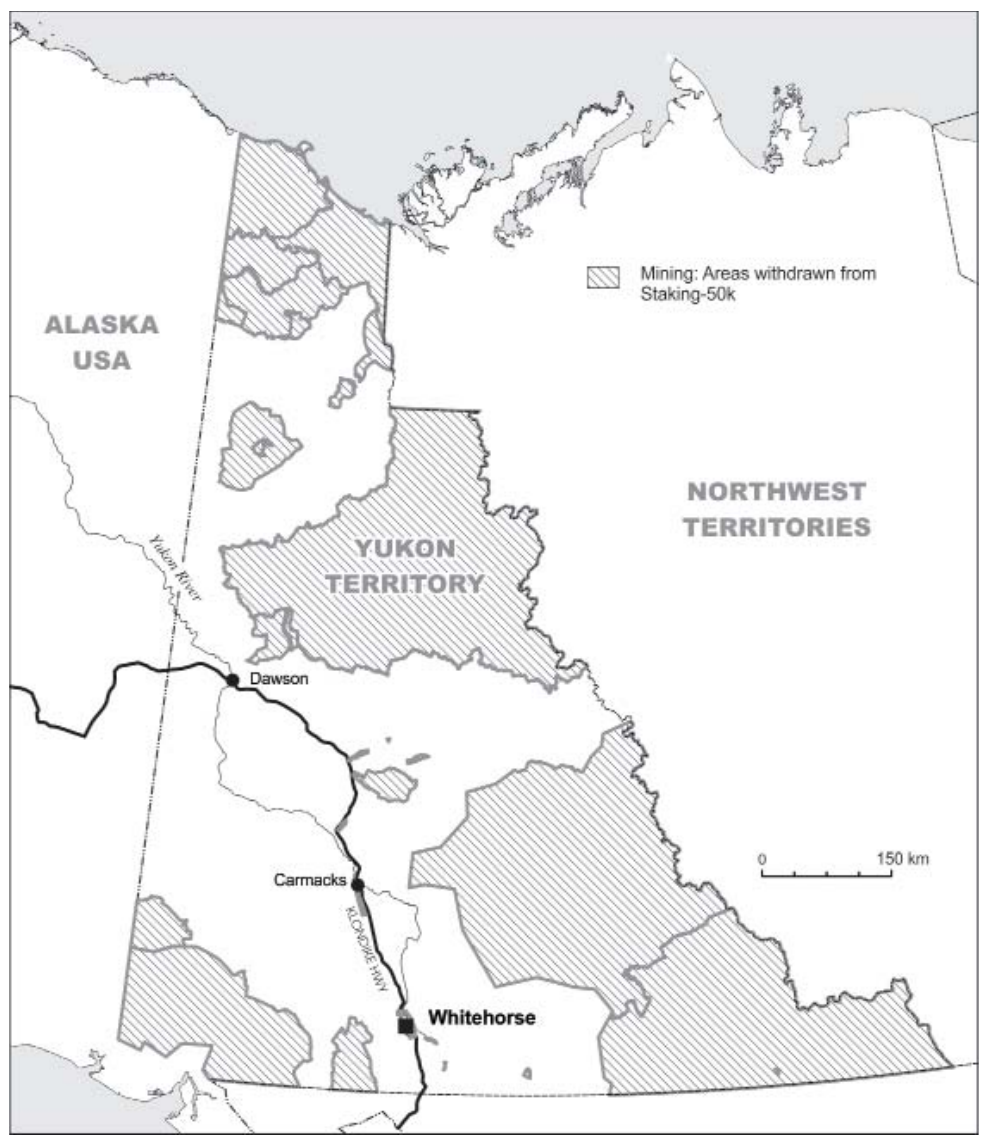

Figure 2. Map of Yukon areas of land withdrawn from mineral staking 
In sum, the right of Yukon First Nations to consent to mine development is manifest within a variety of governance systems and pieces of legislation both explicitly and implicitly, though this right is limited by the location of proposed development. More specifically, consent is evidently required for developments proposed on Category A and Category B settlement lands, where, to date, mining activity is limited. This situation may be proof that settlement lands are serving their intended purpose, or might demonstrate that industry is avoiding proposing development on settlement lands where consent is an evident requirement. How do those who work within the Yukon's key institutions that govern mine development understand rights and obligations regarding consent?

\section{How Are Key Yukon Institutions Engaging with FPIC?}

As a region with both mineral development potential, and visionary Indigenous governance, one might expect the Yukon to be at the forefront of an international discourse that brings these elements together: free, prior, and informed consent (FPIC). Engagement with key institutions in the Yukon during Summer 2017 revealed a different observation. Based upon eleven interviews conducted with key informants from the Yukon government (4), Yukon Environmental and Socio-economic Assessment Board (YESAB) (2), the Water Board (1), Council for Yukon First Nations (CYFN) (1), Yukon Conservation Society (1), and the consulting community (2), it was observed that conversations around resource development in the Yukon are largely silent on the idea of FPIC; as noted by one interviewee, "FPIC is not usually referenced in the discourse here in the Yukon. Why that is, I don't know." Almost unanimously, key informants said that the conversation regarding FPIC is not active within their institution. In the words of a key informant representing a regulatory institution, "In my experience it [FPIC] hasn't come up as often, or as frequently as one would think since the federal adoption [of UNDRIP]." Many others simply noted that, for jurisdictional reasons, FPIC is not the responsibility of the institution they represent. This comment came in several forms: FPIC is "not our business," "not our bag," "not our role," and "not our concern." In the case of YESAB, the Water Board, and CYFN, this jurisdictional rationale seemingly derives from a lack of mandate to address consultation or consent. In the case of the Government of Yukon, within whose jurisdiction consultation, accommodation, and consent conceivably lie, non-engagement with FPIC was attributed to the political need to await anticipated federal action. 
While these reasons offer an explanation for non-engagement, deeper contemplation of the evidence points to factors possibly contributing to the apparent non-engagement with FPIC within key institutions in the Yukon. In the remainder of this section, three possible factors contributing to this non-engagement with FPIC are explored: the impact of modern treaties on Yukon First Nations' consultation and consent rights; the federal government's delay in clearly defining expectations and, or, legislation regarding FPIC; and given the relatively short amount of time since the federal adoption of UNDRIP, a lack of litigation to date regarding FPIC in the context of northern land claims.

Starting with the impact of the modern treaties, key informant interviews made it clear that there is a great deal of respect in the territory for the treaties, which were routinely characterized as the "laws of the land." These laws are seen as setting "clear roles and responsibilities" for parties to resource development and associated negotiations. At the same time, one key informant admitted that "[consent] is not something that we [assessors] concern ourselves with, because for us the rules are pretty clear [from the UFA]. Yes, enshrined in law." The lack of connection between the Yukon's "laws of the land" and the global and national discourse around the right of Indigenous peoples to issue their consent was common. As noted by one key informant: "In the sense of 'how does this current process conform to or contradict the whole notion of consent and FPIC and all that? That type of question has not ... we haven't gotten that." This disconnect is interesting, and perhaps simply explained by the evident authority of the modern treaties that might make explicit attention to a beyond-Yukon discourse unnecessary. In other words, this idea of FPIC, created at the international scale and committed to at a national scale, may not have salience in the Yukon context given the governance systems in place.

Alternatively, limited engagement with the concept of FPIC may be the result of understandable political conservatism mixed with inaction on the part of the federal government, whose FPIC agenda is only partially developed. When prodded about where responsibility lies for the observance of Indigenous consent rights, most key informants pointed to the Yukon government: "no that's easy, it's the Yukon government [whose jurisdiction is consultation and consent]." At the same time, one of these key informants suggested that the government is simply not prepared to address it: "the Yukon government can do that [take a stance on FPIC]. They have a responsibility to do that. I just don't believe that they're prepared to go down that track yet." For many key informants, it is evident that the territorial government is awaiting federal-level initiatives, or at least clarification, 
regarding FPIC before engaging to determine implications in the Yukon governance context.

[The] Yukon government is not a signatory to UNDRIP. That is a federal decision. So basically the government's approach has basically been to look to Canada to see how they are interpreting UNDRIP. And to look at things in the way that they always do, which is with respect to the landscape in the Yukon. So understanding how UNDRIP applies in the context of a largely modern treatied territory [...] Yukon is not going to embark on its own interpretation of Canada's commitment until it is clear from the federal level what it means.

It might not be that FPIC is irrelevant to the Yukon, but that there is no advantage to advancing the conversation at a territorial level before federal expectations are clear. One territorial government representative said that, while waiting for the federal government to clarify the definition of FPIC, the modern treaties are the rules to follow:

we will [continue to] work and wait for the federal ... to kind of see what the feds do. And if that means any changes to us in terms of policy or operationally then we'll look at that. But you know we're quite ... we have the UFA and the final agreements and YESAA established and we're following that.

A third factor possibly influencing the limited engagement with FPIC might simply be time. Perhaps FPIC is a concept and conversation that will inevitably surface in the Yukon, but is being delayed as First Nation governments continue to refine the implementation of their hard-fought treaty rights, which include defining, from the citizens' level, expectations of consent (Martin, 2018). As one key informant noted, "I think in Yukon, NWT and Nunavut, it may take much longer for it [FPIC discourse] to bubble to the surface and boil over." This sentiment was echoed by those key informants who noted, with some surprise, that pressure from First Nation governments and communities to implement FPIC was seemingly modest at present: "There hasn't been any requests, or pressure, or demands by First Nations to think about this [FPIC] more." Another key informant suggested that questions concerning FPIC will soon emerge: "I' $m$ convinced that eventually there will be some court cases around it. And it will be all settled. But I think we are in the early stages of that." 
In summary, all three factors outlined above offer possible insight into the observation that a region of strong and dynamic Indigenous governance might display limited explicit engagement with the concept of consent. Undoubtedly, the presence of modern treaties, including the UFA, final agreements, and self-government agreements, which are widely respected as "the law of the land" and set "clear roles and responsibilities" for assessors, regulators, developers, and First Nations, have created conditions proximate to consent rights on settlement lands. Further, in areas not covered by final agreements, the assertion of authority via litigation, as exemplified by the moratorium on staking in the Ross River area and Kaska-asserted traditional territory, is also serving to establish rights akin to consent. Given this situation, coupled with the ongoing conversations around FPIC at the national level, it is understandable that Yukon officials are hesitant to define and operationalize a consent standard in an explicit way. The same logic holds true for the Yukon's First Nation governments, which understandably may want to take their time in defining their expectations around the issuance of consent to major developments within their territories. How do these possible explanations, and the state of FPIC in the Yukon detailed above, mirror or add to existing knowledge?

\section{Discussion}

The parallels between what was observed in the Yukon in 2017 with respect to explicit engagement with the growing international discourse around FPIC, and existing knowledge of Indigenous resource governance, are many. For example, that the Yukon's First Nation governments might exercise caution in defining their expectations around the issuance of consent, mirrors a common approach to agreement-making in the international mining sector (see O'Faircheallaigh, 2010b). Though many Indigenous governments across Canada are indeed signing agreements that might imply consent, and are even beginning to define FPIC and its associated procedures (see BLC, 2015), the processes for both are onerous and getting them right contextually is critical (Baker \& McLelland, 2003; Booth \& Skelton, 2011; Buxton \& Wilson, 2013; Dokis, 2015; IrlbacherFox, 2009; Mahanty \& McDermott, 2013; Owen \& Kemp, 2014; Papillon \& Rodon, 2017; Ward, 2011). This likely explains why one key informant asserted that conversations and conflict around FPIC are forthcoming ("bubbling $u p^{\prime \prime}$ ) in the Yukon, and have simply been delayed by the need to understand FPIC in the context of Yukon governance. 
Contextual relevance is consistently pointed to in scholarship as a necessity for effective community engagement, negotiation, and legislation (Baker \& McLelland, 2003; Booth \& Skelton, 2011; Buxton \& Wilson, 2013; Dokis, 2015; Irlbacher-Fox, 2009; Mahanty \& McDermott, 2013; Owen \& Kemp, 2014; Papillon \& Rodon, 2017; Ward, 2011). Might this observation, well supported by literature, indicate that it is impossible to create a universal, or even national, definition of FPIC? Might FPIC be formulated to allow a regional approach under some kind of larger and consistent framework? Indeed, this proposed model might even mirror that of the Yukon's modern treaties, where individually negotiated final agreements are nested beneath the larger framework of the Umbrella Final Agreement to account for the unique circumstances of each First Nation. This call for locally appropriate processes highlights the need for better understandings of individual community expectations of the principle and process of FPIC. For a regional approach to FPIC to be realized, the Yukon would need to foster explicit dialogue regarding FPIC, even if exploratory in nature.

\section{Conclusions}

In light of growing awareness of the right to free, prior, and informed Consent (FPIC) as articulated by the United Nations Declaration on the Rights of Indigenous Peoples (UNDRIP), and given recent major mineral development interest in the Yukon, this article has endeavoured to explore the current state of FPIC in the Yukon. With the current federal government publicly agreeing to support and implement UNDRIP and all that it entails (Trudeau, 2015), and the Yukon territorial government specifically vowing to repair relationships with Yukon First Nations (Silver, 2016), one might expect conversations around FPIC to be vibrant in the Yukon. Instead, research presented here reveals limited engagement with the concept among key institutions for reasons that include: the presence of modern treaties; the fact that UNDRIP and the associated right to FPIC is a federal, rather than territorial, commitment; and the need for time for conversation and conflict to mould FPIC into something workable in the Yukon context.

Given the exploratory nature of the research presented herein, more research could be done to make better sense of the evolving place of consent in Yukon's governance and discourse. This area of study could also benefit from further inquiry including how understandings of FPIC are evolving in other territories with modern land claims and selfgovernment. Additionally, as the right to FPIC is meant as an expression 
of self-determination (Anaya, 2009b; Hanna \& Vanclay, 2013; Papillon \& Rodon, 2017; Sambo-Dorough, 2016; Ward, 2011), evolving debates would benefit greatly from dialogue with specific Indigenous communities and governments regarding their unique expectations and understandings of the right to FPIC. Work of this kind is currently underway by the Little Salmon Carmacks First Nation (see Martin, 2018); widespread progress to this end is understandably slow given the significance of the task. For the consent to be operational in the Yukon, as is inferred by the president and CEO of Casino Mining Corporation, one would expect this to be articulated and confirmed by key institutions governing mineral development. Evidence presented herein suggests that these key institutions have neither confirmed the operationalization nor articulated their understanding of FPIC, and cautions that silence cannot be viewed as sanction.

\section{Authors}

Emily M. W. Martin is a master's student studying in the department of geography at the University of Guelph, which is situated on the ancestral lands of the Attawandron people and the treaty lands and territory of the Missasaugas of the Credit.

Ben Bradshaw is associate professor of geography at the University of Guelph.

\section{References}

Anaya, J. (2009a) Report to the Human Rights Council, A/HRC/12/34. (July 15), para 50-53. UN Human Rights Council. New York: United Nations General Assembly.

Anaya J. (2009b). The right of Indigenous peoples to self-determination in the postdeclaration era. In C. Chartres, \& R. Stavenhagen (Eds.), Making the declaration work: The United Nations Declaration on the Rights of Indigenous peoples (pp. 184-199). Copenhagen: International Working Group for Indigenous Affairs.

Anaya, J. (2012). Report of the Special Rapporteur on the Rights of Indigenous Peoples. United Nations. A/HRC/21/47 (July 6). UN Human Rights Council. New York: United Nations General Assembly.

Anaya, J. (2014). Report of the Special Rapporteur on the Rights of Indigenous peoples: The situation of Indigenous peoples in Canada. A/HRC/27/52 (July 4). UN Human Rights Council. New York: United Nations General Assembly.

Axmann, S., \& Gray, B. (2016). Canada: The United Nations Declaration on the Rights of Indigenous Peoples and free, prior and informed consent. Where 
does Canada go from here? McCarthy Tetrault-Mining in the Courts, Year in Review, Volume VI, 1-7.

Baker, D.C., \& McLelland, J.N. (2003). Evaluating the effectiveness of British Columbia's environmental assessment process for First Nations' participation in mining development. Environmental Impact Assessment Review, 23(5), 581-603.

Bennett, C. (2016). Speech Delivered at the United Nations Permanent Forum on Indigenous Issues, New York, May 10. Ottawa: Government of Canada. Retrieved from http://news.gc.ca/web/article-en.do?nid=1064009\&tp=9701

Booth, A.L., \& Skelton, N.W. (2011). Improving First Nations' participation in environmental assessment processes: Recommendations from the field. Impact Assessment and Project Appraisal, 29(1), 49-58.

Boreal Leadership Council. (2015). Understanding successful approaches to FPIC in Canada. Ottawa: Boreal Leadership Council.

Boutilier, S. (2017). Free, prior, and informed consent and reconciliation in Canada: Proposals to implement Articles 19 and 32 of the UN Declaration on the Rights of Indigenous Peoples. Creating Law, Improving Law, 7(1).

Burger J. (2009). Making the Declaration work for human rights in the UN system. In C. Chartres, \& R. Stavenhagen (Eds.), Making the declaration work: The United Nations Declaration on the Rights of Indigenous Peoples (pp. 304-313). Copenhagen:International Work Group for Indigenous Affairs.

Buxton, A., \& Wilson, E. (2013). FPIC and the extractive industries. London, UK: International Institute for Environment and Development.

Coates, K.S., \& Favel, B. (2016). Understanding FPIC: From assertion and assumption on 'free, prior and informed consent' to a new model for Indigenous engagement on resource development. Ottawa: Macdonald Laurier Institute Aboriginal Canada and the Natural Resource Economy Series, 9 (April), $1-34$.

The Canadian Press. (2017, September 2). Trudeau announces \$360-million highway improvementpackageforYukon.GlobeandMail.Retrieved fromhttp://www.cbc. ca/news/canada/north/justin-trudeau-whitehorse-announcement/1.4273401

CBC News. (2013, September 23). First Nation 'not against mining' insists Chief'. CBC News. Retrieved from http://www.cbc.ca/news/canada/north/ first-nation-not-againstmining-insists-chief-1.1865083

Commissioner of Yukon (2013). Placer Mining Act and Quartz Mining Act, Order in Council 2013/224. Whitehorse, Yukon.

Commissioner of Yukon (2017). Placer Mining Act and Quartz Mining Act, Order in Council 2017/26. Whitehorse, Yukon.

Corntassel, J., \& Holder, C. (2008). Who's sorry now? Government apologies, truth commissions, and Indigenous self-determination in Australia, Canada, Guatemala, and Peru. Human Rights Review, 9(4), 465-489.

Council of Yukon First Nations. (1997). Understanding the Yukon Umbrella Final Agreement. Whitehorse, YT. 
Dokis, C.A. (2015). Where the rivers meet: Pipelines, participatory resource management, and Aboriginal-State relations in the Northwest Territories. Vancouver: UBC Press.

Fontana, L. B., \& Grugel, J. (2016). The politics of Indigenous participation through "free prior informed consent": Reflections from the Bolivian Case. World Development, 77, 249-261.

Garrison, L. (2017, July 14). YESAB says Goldcorp failed to consult First Nations, halts Coffee mine assessment. "They just came in and completely failed to read the local landscape." Yukon News. Retrieved from http://www.yukonnews.com/news/yesab-says-goldcorp-failed-to-consult-first-nations-haltscoffee-mine-assessment/

Haida Nation v. British Columbia (Minister of Forests) 2004 SCC 73. https://scc-csC. lexum.com/scc-csc/scc-csc/en/item/2189/index.do

Hanna, P., \& Vanclay, F. (2013). Human rights, Indigenous peoples and the concept of free, prior and informed consent. Impact Assessment and Project Appraisal, 31(2), 146-157.

ILO (2013). Understanding the indigenous and tribal people convention, 1989 (no. 169) Handbook for ILO tripartite constituents. Geneva: ILO. Retrieved from: http://www.ilo.org/global/standards/subjects-cov-\%20ered-by-international labour\%20standards/indigenous-and-tribal-peoples/\%20WCMS_205225/ lang-en/lang- en/index.htm

[IRMA] Initiative for Responsible Mining Assurance. (2017). IRMA standard for responsible mining (Draft 2.0), Chapter 2.10, Free Prior and Informed Consent FPIC. Retrieved from http://www.responsiblemining.net/irmastandard/irma-standard-draft-v2.0/chapter-2.10

Joffe, P. (2010). Canada's opposition to the UN Declaration: Legitimate concern or ideological bias? In J. Heartley, P. Joffe, \& J. Preston (Eds.), Realizing the UN Declaration on the Rights of Indigenous Peoples: Triumph, hope, action (pp. 70-94). Purich Publishing.

Joffe, P. (2015). "Veto" and "consent" significant differences, (July 31), 1-15. Retrieved from https://www.afn.ca/uploads/files/2015_usb_documents/vetoand-consent-significant differences-joffe-final-july-31-15.pdf

Land, L. (2016). Who's afraid of the big bad FPIC? The evolving integration of the United Nations Declaration on the Rights of Indigenous Peoples into Canadian law and policy. Northern Public Affairs, 4(2), 42-49.

MacIntyre, M. (2007). Informed consent and mining projects: A view from Papua New Guinea. Pacific Affairs, 80, 49-65.

Mahanty, S., \& McDermott, C.L. (2013). How does "free, prior and informed consent" (FPIC) impact social equity? Lessons from mining and forestry and their implications for REDD+. Land Use Policy, 35, 406-416.

Martin, E.M.W. (2018 Expected). Free, prior, and informed consent to mine development in the Yukon: Norms, expectations, and the role of novel governance mechanisms. (Master's thesis, Expected Sep 2018). University of Guelph, Guelph, ON. 
Newman, D. (2017). Political rhetoric meets legal reality: How to move forward on free, prior and informed consent in Canada. Ottawa: MacDonald Laurier Institute Aboriginal Canada and the Natural Resources Economy.

Obed, N. (2016). Free, prior \& informed consent and the future of Inuit selfdetermination. Northern Public Affairs, 4(2), 38-41.

O'Faircheallaigh, C. (2010a). Public participation and environmental impact assessment: Purposes, implications, and lessons for public policy making. Environmental Impact Assessment Review, 30(1), 19-27.

O'Faircheallaigh, C. (2010b) Aboriginal-mining company contractual agreements in Australia and Canada: Implications for political autonomy and community development. Canadian Journal of Development Studies, 30(1-2), 69-86.

Owen, J.R., \& Kemp, D. (2014). "Free prior and informed consent," social complexity and the mining industry: Establishing a knowledge base. Resources Policy, 41(1), 91-100.

Papillon, M., \& Rodon, T. (2016). Proponent-Indigenous agreements and the implementation of the right to free, prior, and informed consent in Canada. Environmental Impact Assessment Review, 62, 216-224.

Papillon, M., \& Rodon, T. (2017). Indigenous consent and natural resource extraction foundations for a made-in-Canada approach. IRPP Insight, 16. Montreal: Institute for Research on Public Policy.

Parfitt, T. (2004). The ambiguity of participation: A qualified defense of participatory development. Third World Quarterly, 25(3), 537-555.

Perreault, T. (2015). Performing participation: Mining, power, and the limits of public consultation in Bolivia. Journal of Latin American and Caribbean Anthropology, 20(3), 433-451.

Ross River Dena Council v. Government of Yukon 2012 YKCA 14. http://www. yukoncourts.ca/judgements/appeals/2007/2012_ykca_14_rrdc_v_yukon.pdf

Saganash, R. (2016). In conversation with Northern Public Affairs about the right to free, prior, and informed consent. Northern Public Affairs, 4(2), 16-21.

Sambo Dorough, D. (2016). The right to free, prior \& informed consent in an international context. Northern Public Affairs, 4(2), 33-37.

Shrinkhal, R. (2014). "Free prior informed consent" as a right of Indigenous peoples. Journal of National Law University, Delhi, 2, 55-65.

Silver, S. (2016, November 8). Yukon's next premier Sandy Silver on his election win. $C B C$ News. Retrieved from http://www.cbc.ca/news/canada/north/ yukon-s-next-premier sandysilver-on-his-election-win-1.3841242

St-Laurent, G., \& Le Billon, P. (2015). Staking claims and shaking hands: Impact and benefit agreements as a technology of government in the mining sector. The Extractive Industries and Society, 2, 590-602.

Thomson, N. (2017, January 30). Ross River mineral staking ban extended for one year. CBC News, pp. 8-9. Retrieved from https://www.cbc.ca/news/canada/ north/kaska-ross-river mineral-staking-ban-1.3956430 
Trudeau, J. (2015). Indigenous and Northern Affairs Canada Mandate Letter. Retrieved from http://pm.gc.ca/eng/minister-indigenous-and-northern-affairsmandate-letter

Tsilhqot'in Nation v. British Columbia 2014 SCC 44. https://scc-csc.lexum.com/scccsc/scc-csc/en/item/14246/index.do

Torrence, M. (2017, May 22). Banks look to apply free prior and informed consent in North America. Canadian Mining Journal, 1-2.

United Nations. (2007). United Nations Declaration on the Rights of Indigenous Peoples. UN General Assembly Resolution 61/295, 13 September 2007. http:// www.un.org/esa/socdev/unpfii/documents/DRIPS_en.pdf

United Nations Permanent Forum on Indigenous Issues (UNPFII). (2005). Report of the International Workshop on Methodologies regarding Free, Prior and Informed Consent and Indigenous Peoples, E/C.19/2005/3 (February 17). Permanent Forum on Indigenous Issues. UN Economic and Social Council.

Vanclay F., \& Esteves A.M. (2011). Current issues and trends in social impact assessment. In F. Vanclay \& A.M. Esteves (Eds.), New directions in social impact assessment: Conceptual and methodological advances (pp. 3-19). Cheltenham: Edward Elgar.

Ward, T. (2011). The right to free, prior, and informed consent: Indigenous peoples' participation rights within international law. Northwestern University Journal of International Human Rights, 10(2), 54-84.

Yukon Environmental and Socioeconomic Assessment Act. (S.C. 2003, c. 7). Retrieved from the Justice Laws website: http://laws-lois.justice.gc.ca/eng/acts/ Y2.2/FullText.html

Yukon Government. (2009). Interpretative Bulletin 2009-03 Administration of mineral claims in the traditional territory of First Nations with final agreements (Umbrella Final Agreement). Retrieved from http://www.emr. gov.yk.ca/mining/pdf/ib_2009_03_settlement_lands.pdf 